\title{
The effect of Moringa oleifera leaf meal supplementation on tibia strength, morphology and inorganic content of broiler chickens
}

\author{
T.T. Nkukwana ${ }^{1}$, V. Muchenje ${ }^{1 \#}$, P.J. Masika ${ }^{2}$, L.C. Hoffman ${ }^{3}$ \& K. Dzama ${ }^{3}$ \\ ${ }^{1}$ Department of Livestock and Pasture Science, University of Fort Hare, P. Bag X1314, Alice, 5700, South Africa \\ ${ }^{2}$ Agricultural Development and Research Institute, University of Fort Hare, P. Bag X1314, Alice, 5700, South Africa \\ ${ }^{3}$ Department of Animal Sciences, Stellenbosch University, P. Bag X1, Matieland 7602, South Africa
}

(Received 26 July 2013; Accepted 23 June 2014; First published online 13 August 2014)

\author{
Copyright resides with the authors in terms of the Creative Commons Attribution 2.5 South African Licence. \\ See: http://creativecommons.org/licenses/by/2.5/za \\ Condition of use: The user may copy, distribute, transmit and adapt the work, but must recognise the authors and the South African \\ Journal of Animal Science
}

\begin{abstract}
This study was conducted to assess the effects of dietary Moringa oleifera leaf meal (MOLM) supplementation as a possible alternative to antibiotic growth promoters on bone breaking strength (BBS), tibia bone morphology and inorganic ash content in broiler chickens. A total of 2400 one-day-old Cobb-500 broiler chicks of mixed sex were randomly allocated to five dietary treatments in six replications of 80 birds per pen. Dietary treatments were as follows: T1, positive control, $668 \mathrm{~g}$ salinomycin and $500 \mathrm{~g}$ zinc bacitracin per $\mathrm{kg}$ of feed; T2, T3 and T4, graded levels of MOLM, that is (starter (1, 3 and $5 \mathrm{~g}$ ), grower (3, 9 and $15 \mathrm{~g}$ ) and finisher (5, 15 and $25 \mathrm{~g})$ ) per $\mathrm{kg}$ of feed; and $\mathrm{T} 5$, a negative control (without supplementation). Birds were provided with feed and water ad libitum. Bodyweights (BW) and feed intake (FI) of broilers were measured weekly, and feed conversion ratio (FCR) and average daily gains were calculated accordingly. At 35 days (d) of age, 12 birds per treatment, two from each replicate pen, were randomly selected, stunned electrically at 70 volts, and slaughtered by cervical dislocation. Six left and right tibiae were randomly chosen from each treatment, without being de-fleshed, and were sealed individually in plastic bags to minimize moisture loss. The tibiae were stored at $-18^{\circ} \mathrm{C}$ for BBS and tibia ash determination, as well as analyses of their calcium ( $\mathrm{Ca}$ ) and phosphorus (P) composition. Of birds fed diets with higher MOLM levels, T4 had the highest BW, while T1 had the lowest. On days 7 and 21, birds on T4 had the highest average daily gain (ADG) and T1 the lowest, respectively. There were no significant dietary effects in FI on days 7, 21 and 35; while on days 21 and 35, FCR (feed : gain) was highest in MOLM-supplemented birds and lowest in T1 birds, respectively. There were no treatment effects on tibia length (TL), tibia weight (TW) and/or dried tibia weight (DW). A positive correlation $(r=0.667)$ was observed between TW and DW. There were no treatment effects on BBS and ash percentage, but tibia ash weight was highest in T4 and lowest in T2. Calcium percentage was highest in T1, and lowest in T2 and T5. Phosphorus percentage was lowest in T1 and highest in $\mathrm{T} 5$. The highest $\mathrm{Ca}: \mathrm{P}$ ratio was obtained in $\mathrm{T} 4$. The positive correlation observed between $\mathrm{BW}$, TW and TL, and the high P, Ca and ash levels in tibiae from MOLM-supplemented birds depicts the genetic relationship that exists among these parameters. Furthermore, it reveals the effectiveness of MOLM supplementation to enhance nutrient utilization efficiency, increase mineral bioavailability and support bone strength.
\end{abstract}

Keywords: Bone quality, calcium, Cobb-500 broilers, antibiotic growth promoters, phosphorus

\# Corresponding author: vmuchenje@ufh.ac.za

\section{Introduction}

Bone characteristics are of paramount importance in broiler production, in addition to digestibility and efficiency of feed utilization and gut health (Applegate \& Lilburn, 2002). The bone is a living tissue, a composite material of $30 \%$ organic matrix and $70 \%$ hydroxyapatite, composed mainly of calcium (Ca) and phosphorus (P) in the weight ratio of 2.15: 1 (Whitehead, 2007). Bone ash content and bone breaking strength (BBS) are the most commonly used parameters for assessing the bioavailability of calcium and phosphorus (EMFEMA, 2002; Shaw et al., 2010). Long bones, particularly the tibia, experience cellular sensitivity to numerous dietary deficiencies (Leach \& Lilburn, 1992). The weight of tibia ash has been found to be a sensitive indicator of the amount of available $\mathrm{Ca}$ and $\mathrm{P}$ in the diet (Hall et al., 2003). Moreover, traditionally, estimates of $\mathrm{P}$ needs for growing broilers have been estimated primarily on tibia ash values 
(NRC, 1994). In modern meat-type chickens, bone strength and development are closely linked to the expression of genetic potential for maximum lean muscle deposition (Williams et al., 2004). Thus, the increase in dry bone weight and mineral content per unit bone length responds to mechanical forces placed on the bone (McDevitt et al., 2006; Whitehead, 2007; Talaty et al., 2009a). Skeletal integrity of broiler chickens has become a welfare and economic concern (Williams et al., 2004; Almeida Paz \& Bruno, 2006; Fleming, 2008). Weak bones are an undesirable trait in growing broiler chickens, which has been linked to $1.1 \%$ mortality of birds, and an additional $2.1 \%$ condemnation or downgrading of carcasses during processing (Onyango et al., 2006; Talaty et al., 2009b).

Bone health problems in chickens are reduced by activity and genetic selection, but nutrition is important as a mitigation strategy to ensure that dietary $\mathrm{Ca}$, vitamin $\mathrm{D}$ and $\mathrm{P}$ are adequate and are correctly balanced (Fleming, 2008). Absorption and homeostasis of these minerals depend on their dietary ratio, with maximum absorption obtained at 2Ca : 1P often met by supplying NRC (1994) recommendations of $10 \mathrm{~g}$ Ca and $4.5 \mathrm{~g}$ available P/kg in the broiler starter diet. Broilers are more sensitive to imbalances in mineral supply in their diets (McDevitt et al., 2006). Major ingredients in poultry diets are of plant origin and have approximately $60 \%$ - $80 \%$ of phosphorus in phytic acid form and/or its salt phytate, rendering it biounavailable (Rao et al., 1999; Foidl et al., 2001). A high molar Ca : phytate ratio in the diet may lead to the formation of extremely insoluble Ca-phytate complexes under intestinal conditions, making the phytate molecule inaccessible to the phytase enzyme (Kornegay, 1999). Inadequate dietary sources of calcium result in blood hypocalcaemia, leading to reduced bone strength and mineralization (Talaty et al., 2009a). Typically, supplementation of the phytase enzyme in grain-based poultry diets has become common practice to increase phosphorus bioavailability by $25 \%$ - 50\%, reduce phosphorus excretion by $15 \%$ - $40 \%$, and ensure proper growth and bone development (Harter-Dennis, 1999; Onyango et al., 2006; Coon \& Manangi, 2008).

Until recently, the prophylactic use of antibiotic growth promoters in poultry diets improved feed conversion efficiency and further enhanced the digestibility of $\mathrm{Ca}, \mathrm{P}$ and $\mathrm{Mg}$ in the diet. However, after a ban was imposed in the European Union (EU), research efforts to replace them with natural feed additives such as Moringa oleifera leaves have increased. Moringa oleifera leaves are reported to have potential prebiotic effects and potentially antioxidant phytochemicals, such as chlorogenic acid and caffeic acid (Mbikay, 2012). Caffeic acid has been shown to have powerful inhibitory effects on osteoclastogenesis. Nutritional characterization of dried $M$. oleifera leaves revealed much lower levels of calcium, phosphorus and magnesium contents of 3.65\%, 0.3\% and 0.5\%, respectively (Moyo et al., 2012). Fresh M. oleifera leaves have $\mathrm{Ca}$ and $\mathrm{P}$ contents of $440 \mathrm{mg} / 100 \mathrm{~g}$ and $70 \mathrm{mg} / 100 \mathrm{~g}$, respectively (Joshi \& Mehta, 2010), and up to 21 $\mathrm{g} / \mathrm{kg}$ phytate (Makkar \& Becker, 1997). The underlying effects of the bioactive compounds in $M$. oleifera leaves are not clear. However, they are believed to induce prebiotic effects resulting in increased solubility of minerals because of increased bacterial production of short-chain fatty acids, degradation of mineral complexing phytic acid, and release of bone-modulating factors such as phyto-steroids from the diet (Scholtz et al., 2007). Similar effects have been observed in the presence of antibiotic growth promoters. The current study was therefore designed to assess the potential of using $M$. oleifera leaf meal as an alternative antibiotic growth promoter on BBS, tibia morphology and tibia ash weight when supplemented in broiler diets.

\section{Materials and Methods}

The fresh, green and undamaged mature $M$. oleifera leaves used in this study were collected during the month of June from a number of trees from the same village to avoid variations in soil micronutrient content. The leaves were air-dried during the day with no direct sunlight exposure. During drying, the leaves were turned over constantly to avert fungal growth. After 5 days of drying, the leaves were ground to a fine powder to pass through a $0.15 \mathrm{~mm}$ sieve. The leaf meal was tightly packaged in polythene plastic bags, sealed, and kept at room temperature until required. The nutrient content of the experimental diets and MOLM samples (Table 1) was determined on the basis of moisture, crude protein, ash and ether extract; as well as the mineral composition according to methods of the Association of Official Analytical Chemists (AOAC, 2000). The techniques described by Van Soest et al. (1991) were used to determine neutral detergent fibre (NDF) and acid detergent fibre (ADF) concentrations. The metabolizable energy (ME) content of the diets was calculated based on determined nutrients in the proximate analyses as follows:

$[(3.7 \times$ protein $)+(8.84 \times$ total fat $)+(3.75 \times$ carbohydrates $)=138 \mathrm{kcal} / 100 \mathrm{~g}$ feed $]$

( $\times$ 4.184; to convert kcal to $\mathrm{kJ})$.

The feeding programme consisted of starter (0 to $21 \mathrm{~d}$ ), grower (22 to $28 \mathrm{~d}$ ), and finisher (29 to $35 \mathrm{~d}$ ) basal diets (Table 3), which were formulated to meet the birds' dietary nutrient requirements (NRC, 1994). Each basal feed was split into five treatment (T) groups: T1, positive control, basal diet supplemented with $668 \mathrm{~g}$ salinomycin/ton and $500 \mathrm{~g}$ albac/ton; T2, T3 and T4, basal diet supplemented with graded levels of MOLM (Table 2), and T5, a negative control, basal diet with no supplementation. Inclusion levels of 
M. oleifera leaf meal were increased with change in phase feeding: 1,3 and $5 \mathrm{~g}$ (starter); 3,9 and $15 \mathrm{~g}$ (grower) and 5, 15 and $25 \mathrm{~g}$ (finisher) per kg of feed. All diets from starter to finisher were pelleted.

Table 1 Analysed Moringa oleifera leaf meal (MOLM) composition

\begin{tabular}{lr} 
Analysed nutrient composition in g/kg unless where stated & \\
Metabolizable energy $(\mathrm{MJ} / \mathrm{kg})$ & 11.4 \\
Crude protein & 267.6 \\
Crude fibre & 157.2 \\
Ether extract & 56.3 \\
Moisture & 78.3 \\
Ash & 108.1 \\
Acid detergent fibre & 137.9 \\
Neutral detergent fibre & 200.8 \\
& \\
\hline Analysed mineral composition in mg/kg unless where stated & 3.2 \\
Phosphorus $(\mathrm{g} / \mathrm{kg})$ & 24.3 \\
Potassium $(\mathrm{g} / \mathrm{kg})$ & 28.1 \\
Calcium $(\mathrm{g} / \mathrm{kg})$ & 10.1 \\
Magnesium $(\mathrm{g} / \mathrm{kg})$ & 8.0 \\
Sodium $(\mathrm{g} / \mathrm{kg})$ & 192.0 \\
Iron & 5.7 \\
Copper & 23.8 \\
Zinc & 86.8 \\
Manganese & 33.1 \\
Boron & 160.0 \\
Aluminium & \\
\hline
\end{tabular}

Table 2 Dietary inclusion levels of Moringa oleifera leaf meal (MOLM)

\begin{tabular}{lcccc}
\hline \multirow{2}{*}{ Phase feeding regimen } & \multicolumn{3}{c}{ Dietary treatments (MOLM g/kg feed) } \\
\cline { 2 - 4 } & T2 & T3 & T4 \\
\hline Starter (0 to 21 d) & 1 & 3 & 5 \\
Grower (22 to 27 d) & 3 & 9 & 15 & 25 \\
Finisher (28 to 35 d) & 5 & 15 & \\
\hline
\end{tabular}

A total of 2400 day-old Cobb-500 broiler chicks of mixed sex were purchased from a commercial hatchery, weighed and randomly allocated to 30 floor pens containing fresh wood shavings to the depth of $10 \mathrm{~cm}$ in an environmentally controlled house. The experiment was a completely randomized design divided into five dietary treatments with six replicate groups of 80 birds per pen ( 5 diets $\times 6$ replicates). House temperature was set and maintained at $34^{\circ} \mathrm{C}$ during the first week, then reduced by $3{ }^{\circ} \mathrm{C}$ per week until $22{ }^{\circ} \mathrm{C}$ was reached, and was maintained at this level until the end of the experiment. Birds were vaccinated for Marek's disease and infectious bursal disease at hatchery, but no vaccines were administered during rearing. Chicks were inspected daily, and dead birds were removed after recording mortality (pen, date and BW). Feed and fresh water were offered ad libitum throughout the 35-day rearing period. Care and management of birds were in accordance with principles of animal care in experimentation (NRC, 1985). The 
experiment was subjected to an assessment for its ethical acceptability and approved by the Ethics Committees of the University of Fort Hare (Animal Ethics No.: NKU01-1SWAP01).

At 35 days of age, 12 birds were randomly selected per treatment, two per replicate pen (pen means served as the experimental unit for statistical analysis), and were individually weighed to ascertain whether they represented the average pen weight. Birds were then fasted for 8 hours with water offered ad libitum, and were reweighed before they were slaughtered by cervical dislocation following electrical stunning at 70 volts. After bleeding, scalding, plucking and washing, the feet, head and neck were removed. The left and right tibiae from six birds per treatment were randomly chosen; without being de-fleshed, and were individually sealed in plastic bags to minimize moisture loss. Tibiae were stored at $-18^{\circ} \mathrm{C}$ for $\mathrm{BBS}$ and tibia ash determination, as well as the analyses of their calcium (Ca) and phosphorus $(\mathrm{P})$ composition.

Table 3 Composition of basal starter, grower, and finisher diets on as fed basis

\begin{tabular}{lccc}
\hline & \multicolumn{3}{c}{ Phase feeding regimen } \\
\cline { 2 - 4 } Item & Starter & Grower & Finisher \\
& $(0$ to $21 \mathrm{~d})$ & $(22$ to $27 \mathrm{~d})$ & $(28$ to $35 \mathrm{~d})$ \\
\hline
\end{tabular}

Feed ingredients $(\mathrm{g} / \mathrm{kg})$

$\begin{array}{lrrr}\text { Fine maize } & 610.3 & 664.4 & 660.4 \\ \text { Soya oilcake } & 311.5 & 249.1 & 253.5 \\ \text { Fishmeal } & 25.4 & 33.3 & 40.0 \\ \text { Sunflower oil } & 20.0 & 25.0 & 16.9 \\ \text { Limestone } & 14.8 & 14.0 & 13.6 \\ \text { Monocalcium phosphate } & 8.6 & 7.1 & 7.6 \\ \text { Methionine } & 3.1 & 1.7 & 2.4 \\ \text { Salt } & 3.3 & 2.9 & 3.1 \\ \text { *Vitamin + mineral premix } & 1.2 & 1.2 & 1.2 \\ \text { Sodium Bicarbonate } & 0.9 & & 0.2 \\ \text { Choline Chloride } & 0.8 & 0.5 & 0.8 \\ \text { Lysine } & 0.2 & 0.6 & 0.3 \\ \text { Treonine } & 0.1 & 0.2 & \end{array}$

Analysed composition ( $\mathrm{g} / \mathrm{kg})$

Crude protein

Crude fibre

Ether extract

Calcium

Available phosphorus

Calculated composition

Metabolizable energy ( $\mathrm{MJ} / \mathrm{kg})$

$\begin{array}{rr}246.2 & 206.6 \\ 30.9 & 14.1 \\ 50.0 & 54.7 \\ 11.2 & 10.1 \\ 7.7 & 7.8\end{array}$

206.6

200.6

14.1

32.8

54.7

45.2

9.8

6.8

14.08

*Supplied per kg of feed: $60 \mathrm{mg}$ iron; $40 \mathrm{mg}$ manganese; $4 \mathrm{mg}$ copper; $70 \mathrm{mg}$ zinc; $0.8 \mathrm{mg}$ iodine; $0.3 \mathrm{mg}$ selenium; 9000 IU vitamin A; $2000 \mathrm{IU}$ vitamin D; $15 \mathrm{IU}$ vitamin E; $2 \mathrm{mg}$ vitamin K; $1 \mathrm{mg}$ vitamin $\mathrm{B}_{12} ; 0.30 \mathrm{mg}$ biotin; $250 \mathrm{mg}$ choline chloride; $0.75 \mathrm{mg}$ folic acid; $20 \mathrm{mg}$ niacin; $5.3 \mathrm{mg}$ pantothenic acid; $7.5 \mathrm{mg}$ pyridoxine; $7.5 \mathrm{mg}$ riboflavin; $2.1 \mathrm{mg}$ thiamine.

When ready for use, tibiae were defrosted overnight at $4{ }^{\circ} \mathrm{C}$. After thawing, they were de-fleshed and cleaned of all tissue, including cartilage caps (periosteum) by hand, and weighed. The length $(\mathrm{cm})$ of each bone was determined with a ruler (the cross-section area was not calculated). The breaking strength of each tibia was determined by the three-point bending test using an Instron 4502 (Instron Ltd., High Wycombe, UK) material testing machine with default specimen dimensions setup as circular geometry, $10 \mathrm{~mm}$ diameter, anvil height of $30 \mathrm{~mm}$ and crosshead speed of $50 \mathrm{~mm} / \mathrm{min}$. Vertical hydraulic force was applied at the 
midpoint of the bone shaft to minimize splintering. The load, defined as force (Newton $(\mathrm{N})$ ) of cross-sectional area, represented bone strength, while the modulus measured rigidity, as related to stress and strain.

Table 4 Analysed nutrient composition of the experimental diets and MOLM on dry matter basis in $\mathrm{g} / \mathrm{kg}$

\begin{tabular}{|c|c|c|c|c|c|c|c|c|}
\hline $\begin{array}{c}\text { Dietary } \\
\text { treatment }\end{array}$ & $\begin{array}{c}\mathrm{ME} \\
(\mathrm{MJ} / \mathrm{kg})\end{array}$ & $\begin{array}{c}\mathrm{CP} \\
(\mathrm{g} / \mathrm{kg})\end{array}$ & $\begin{array}{c}\mathrm{CF} \\
(\mathrm{g} / \mathrm{kg})\end{array}$ & $\begin{array}{c}\mathrm{EE} \\
(\mathrm{g} / \mathrm{kg})\end{array}$ & $\begin{array}{c}\text { ADF } \\
(\mathrm{g} / \mathrm{kg})\end{array}$ & $\begin{array}{c}\text { NDF } \\
(\mathrm{g} / \mathrm{kg})\end{array}$ & $\begin{array}{c}P \\
(\mathrm{~g} / \mathrm{kg})\end{array}$ & $\begin{array}{c}\mathrm{Ca} \\
(\mathrm{g} / \mathrm{kg})\end{array}$ \\
\hline \multicolumn{9}{|c|}{ Starter (1 to 21 days) } \\
\hline T1 & 13.9 & 224 & 37 & 44 & 46 & 110 & 10 & 10 \\
\hline T2 & 13.9 & 235 & 40 & 47 & 46 & 105 & 10 & 10 \\
\hline T3 & 13.8 & 241 & 46 & 49 & 52 & 102 & 11 & 10 \\
\hline T4 & 14.1 & 239 & 37 & 57 & 41 & 111 & 10 & 13 \\
\hline T5 & 14.0 & 246 & 37 & 50 & 35 & 109 & 11 & 11 \\
\hline \multicolumn{9}{|c|}{ Grower (22 to 27 days) } \\
\hline $\mathrm{T} 1$ & 14.0 & 196 & 43 & 51 & 54 & 134 & 7.0 & 10 \\
\hline T2 & 13.9 & 196 & 42 & 55 & 46 & 134 & 7.0 & 10 \\
\hline T3 & 13.9 & 204 & 41 & 54 & 43 & 140 & 8.0 & 11 \\
\hline T4 & 13.8 & 205 & 40 & 47 & 50 & 122 & 8.0 & 11 \\
\hline T5 & 14.0 & 207 & 44 & 55 & 55 & 109 & 8.0 & 10 \\
\hline \multicolumn{9}{|c|}{ Finisher ( 28 to 35 days) } \\
\hline $\mathrm{T} 1$ & 13.7 & 217 & 43 & 49 & 59 & 110 & 7.0 & 11 \\
\hline $\mathrm{T} 2$ & 13.9 & 210 & 40 & 50 & 47 & 133 & 7.0 & 10 \\
\hline T3 & 13.7 & 222 & 36 & 46 & 44 & 119 & 7.0 & 11 \\
\hline T4 & 13.6 & 218 & 42 & 47 & 56 & 124 & 7.0 & 11 \\
\hline T5 & 13.8 & 201 & 40 & 45 & 50 & 123 & 7.0 & 10 \\
\hline
\end{tabular}

$\mathrm{T}_{1}$, positive control, $668 \mathrm{mg}$ salinomycin, $500 \mathrm{mg}$ zinc bacitracin; $\mathrm{T}_{2}, \mathrm{~T}_{3}$ and $\mathrm{T}_{4}$, graded levels of MOLM;

$\mathrm{T}_{5}$ : a negative control diet with no supplementation.

$\mathrm{CP}$ = crude protein; $\mathrm{ME}$ = metabolizable energy; $\mathrm{CF}$ = crude fibre; $\mathrm{EE}=$ ether extract $\mathrm{ADF}=$ acid detergent fibre;

NDF = neutral detergent fibre.

Sheared tibiae pieces were collected and dried at $100{ }^{\circ} \mathrm{C}$ for 24 hours, cooled in a desiccator, and defatted by soaking in $200 \mathrm{~mL}$ anhydrous ether for $24 \mathrm{~h}$ to remove moisture, as well as polar and non-polar lipids. The dried fat-free bones were weighed, then ashed in a muffle furnace overnight at $600^{\circ} \mathrm{C}$. The ash was weighed. Tibiae were analysed for $\mathrm{Ca}$ and $\mathrm{P}$ composition. Percentage of tibia ash was calculated as (tibia ash weight $\div$ tibia dry weight) $\times 100$; and tibia ash index was calculated as tibia ash percentage $\div$ tibia length.

The morphological, physical and chemical data were subjected to analysis of variance (ANOVA) using SPSS (2011) to determine the effect of dietary treatments. Duncan's multiple range test was used to compare treatment means. Data were presented as the least square means with standard error. The bodyweights (BW), BBS, tibia weight (TW), dried tibia weight (DW) and tibia ash mineral content (Ca and P) were regressed against tibia ash percentage. Pearson correlation coefficients between BW, tibia characteristics, tibia ash and mineral content ( $\mathrm{Ca}$ and P) were calculated using SPSS (2011). Differences were considered significant at $P<0.05$. The model was:

$$
Y_{i j}=\mu+\alpha_{i}+e_{i j}
$$

where $Y_{i j}=$ response variable, $\mu=$ the common mean, $\alpha_{i}=$ the effect of dietary treatment $(T 1, T 2, T 3, T 4$ and $\mathrm{T} 5)$ and $\mathrm{e}_{\mathrm{ij}}=$ the random error.

\section{Results and Discussion}

Body weight, average daily gain (ADG), feed intake (FI) and feed : gain ratio (FCR) values at days 7 , 21 and 35 are presented in Table 5. There were no differences in BW at placement and at d 35. However, on 
d 7 and 21, birds on T4 had the highest BW $(P<0.05)$, while T1 had the lowest, respectively. Similarly, on d 7 and 21, birds on T4 had the highest $(P<0.05)$ ADGs, and were lowest in T1, respectively. The results of the current study indicated that MOLM exerted a feed intake regulating effect in broiler chickens at dietary inclusion levels ranging between 1 and $25 \mathrm{~g} / \mathrm{kg}$ in starter, grower and finisher diets, respectively. There were no significant dietary effects $(P>0.05)$ in FI on d 7, 21 and 35, while on d 21 and d 35, FCR was significantly higher in birds that were fed diets supplemented with MOLM and was lower in T1 birds $(P<0.05)$.

The present findings seem to agree with previous reports that plant extracts have an influence on $\mathrm{FI}$ and FCR. Although in a number of cases FI and FCR were not changed, the extracts had positive effects on BW, ADG and energy utilization (Wallace et al., 2010). Phenolic acids used as additives have beneficial effects on nutrient utilization by stimulating the production of digestive enzymes such as trypsin and amylase (Windisch et al., 2008). Similar findings on growth performance and digestive organ size were observed by Nkukwana et al. (2014). Other authors have shown that cinnamic acid, a phenolic acid present in M. oleifera leaves, can cause increased glycolysis and increased utilization of glucose for energy production (Kasetti et al., 2012; Mbikay, 2012). This may justify the increased BW and FCR in birds that were supplemented with MOLM in their diets, a response that is often observed with in-feed antibiotic inclusion. On the other hand, dietary cholecalciferol or $\mathrm{P}$ was reported to improve BW gain, $\mathrm{FI}$, feed efficiency and percentage tibia ash of broiler chicks (Onyango et al., 2006).

Table 5 Effect of diets supplemented with or without Moringa oleifera leaf meal (MOLM) on bodyweight, average daily gain, feed intake and feed conversion ratio (feed : gain) of broilers chickens

\begin{tabular}{llllllll}
\hline $\begin{array}{l}\text { Experimental period } \\
\text { (d) and parameter }\end{array}$ & \multicolumn{5}{c}{ Dietary Treatments } & \multirow{2}{*}{ SEM } & $P$-value \\
\cline { 2 - 7 } & T1 & T2 & T3 & T4 & T5 & & \\
\hline
\end{tabular}

\begin{tabular}{|c|c|c|c|c|c|c|c|}
\hline \multicolumn{8}{|c|}{ Bodyweight(g) } \\
\hline $0 \mathrm{~d}$ & 45 & 46 & 45 & 46 & 46 & 0.2 & 0.818 \\
\hline $7 d$ & $165^{\mathrm{b}}$ & $176^{\mathrm{ab}}$ & $176^{\mathrm{ab}}$ & $181^{\mathrm{a}}$ & $172^{\mathrm{ab}}$ & 1.5 & 0.010 \\
\hline $21 \mathrm{~d}$ & $888^{b}$ & $928^{\mathrm{a}}$ & $932^{\mathrm{a}}$ & $955^{a}$ & $919^{\mathrm{ab}}$ & 5.5 & $<0.001$ \\
\hline $35 d$ & 2119 & 2147 & 2236 & 2174 & 2177 & 14.0 & 0.094 \\
\hline \multicolumn{8}{|c|}{ Average daily gain $(\mathrm{g})$} \\
\hline $7 d$ & $23.6^{c}$ & $25.2^{\mathrm{ab}}$ & $25.1^{\mathrm{ab}}$ & $25.8^{\mathrm{a}}$ & $24.6^{\mathrm{bc}}$ & 0.1 & 0.010 \\
\hline $21 \mathrm{~d}$ & $42.3^{b}$ & $44.2^{\mathrm{a}}$ & $44.4^{\mathrm{a}}$ & $45.5^{\mathrm{a}}$ & $43.7^{\mathrm{ab}}$ & 0.3 & $<0.001$ \\
\hline $35 d$ & 60.6 & 61.3 & 63.9 & 62.1 & 62.2 & 0.4 & 0.094 \\
\hline \multicolumn{8}{|c|}{ Feed intake (g) } \\
\hline $7 \mathrm{~d}$ & 153 & 157 & 152 & 158 & 149 & 1.4 & 0.246 \\
\hline $21 d$ & 1087 & 1042 & 1101 & 1084 & 1043 & 9.0 & 0.120 \\
\hline $35 d$ & 3230 & 3160 & 3219 & 3147 & 3109 & 18.9 & 0.218 \\
\hline \multicolumn{8}{|c|}{ Feed : gain (g:g) } \\
\hline $7 \mathrm{~d}$ & 1.08 & 1.12 & 1.16 & 1.14 & 1.17 & 0.01 & 0.173 \\
\hline $21 \mathrm{~d}$ & $1.22^{b}$ & $1.12^{\mathrm{a}}$ & $1.18^{\mathrm{ab}}$ & $1.14^{\mathrm{a}}$ & $1.14^{\mathrm{a}}$ & 0.01 & 0.013 \\
\hline $35 d$ & $1.53^{b}$ & $1.47^{\mathrm{ab}}$ & $1.44^{\mathrm{a}}$ & $1.45^{\mathrm{a}}$ & $1.43^{\mathrm{a}}$ & 0.01 & 0.053 \\
\hline
\end{tabular}

a-c Means within the same row that do not share a common superscript are significantly different $(P<0.05)$. n $=6$. $\mathrm{T}_{1}$, positive control, $668 \mathrm{mg}$ salinomycin, $500 \mathrm{mg}$ zinc bacitracin; $\mathrm{T}_{2}, \mathrm{~T}_{3}$ and $\mathrm{T}_{4}$ contained graded levels of MOLM; $\mathrm{T}_{5}$ : a negative control diet with no supplementation.

Table 6 shows the effects of diets supplemented with or without $M$. oleifera leaf meal on tibia morphology (weight and length) before and after drying and removal of fat, as well as on BBS. The dietary supplementation of MOLM had no significant effect on tibia characteristics. No statistical differences were observed on TW among treatment groups, although T1 tibiae were lighter, even after drying. Tibiae from T2 birds were longer than those in other treatments, while those from T4 birds were shorter. Although no treatment effects were observed in the TW/tibia length (TL) ratio, it was higher in T3, T4 and T5; and lower in T1. The dried defatted tibiae (DW) were heavier in T3 (11.20 \pm 0.347$)$ and lighter in T1 (9.44 \pm 0.562$)$ birds. 
Nonetheless, LW, which is the difference between TW and DW, was lowest in T1 and highest in T3, although it was generally higher in tibiae from birds that were supplemented with MOLM. Previously, a depression in BW and tibia ash has been reported in diets with lowest available P and increased Ca levels without phytase supplementation (Yan et al., 2006).

Table 6 Least square means ( \pm standard errors) of tibia characteristics of broilers (35 d) fed diets supplemented with or without Moringa oleifera leaf meal (MOLM)

\begin{tabular}{lcccccc}
\hline \multirow{2}{*}{$\begin{array}{l}\text { Variable } \\
(\mathbf{n}=\mathbf{6})\end{array}$} & \multicolumn{7}{c}{ Dietary treatments } & P-value \\
\cline { 2 - 7 } & T1 & T2 & T3 & T4 & T5 \\
\hline TL (cm) & $9.8 \pm 0.09$ & $10.0 \pm 0.04$ & $9.9 \pm 0.01$ & $9.6 \pm 0.04$ & $9.8 \pm 0.25$ & 0.229 \\
TW (g) & $10.0 \pm 0.60$ & $11.1 \pm 0.46$ & $11.7 \pm 0.79$ & $11.4 \pm 0.86$ & $11.6 \pm 0.35$ & 0.322 \\
DW (g) & $9.4 \pm 0.56$ & $10.5 \pm 0.49$ & $11.2 \pm 0.35$ & $10.7 \pm 0.62$ & $11.1 \pm 0.33$ & 0.116 \\
LW (g) & $2.4^{\mathrm{b}} \pm 0.74$ & $5.0^{\mathrm{a}} \pm 0.26$ & $5.8^{\mathrm{a}} \pm 0.22$ & $5.5^{\mathrm{a}} \pm 0.24$ & $5.7^{\mathrm{a}} \pm 0.13$ & $<0.001$ \\
TW/TL (g/cm) & $1.0 \pm 0.06$ & $1.1 \pm 0.05$ & $1.2 \pm 0.08$ & $1.2 \pm 0.09$ & $1.2 \pm 0.04$ & 0.274 \\
Tibia ash index & $5.0 \pm 0.09$ & $4.9 \pm 0.03$ & $4.9 \pm 0.05$ & $5.0 \pm 0.02$ & $4.9 \pm 0.12$ & 0.454 \\
BBS (N) & $395.0 \pm 38.83$ & $346.9 \pm 41.26$ & $371.9 \pm 24.75$ & $375.8 \pm 34.09$ & $338.3 \pm 22.86$ & 0.753
\end{tabular}

${ }^{\mathrm{a}, \mathrm{b}, \mathrm{c}, \mathrm{d}, \mathrm{e}}$ Means within a row with no common superscript differ significantly $(P<0.05)$.

$T_{1}$, positive control, $668 \mathrm{mg}$ salinomycin, $500 \mathrm{mg}$ zinc bacitracin; $\mathrm{T}_{2}, \mathrm{~T}_{3}$ and $\mathrm{T}_{4}$ contained graded levels of $M$. oleifera leaf meal (MOLM); and $T_{5}$ : a negative control diet with no supplementation.

TW = tibia weight; TL = tibia length; DW = dried defatted tibia weight; LW = loss in tibia weight;

$\mathrm{BBS}=$ bone breaking strength.

Usually the greatest need for nonphytate $\mathrm{P}$ is for improvement in tibia ash, followed by BW and feed conversion efficiency (Yan et al., 2001), which was partly the case in the current study. Other authors reported an increase in total gain and improvement in tibia breaking strength at four weeks of age when the dietary concentration of nonphytate $P$ was $0.5 \%$ in comparison with a diet containing only $0.35 \%$ (Shaw et al., 2010). As a result, in instances where phytase is supplemented, the higher BW gain may be attributable to an increase in P availability and possibly feed intake (Rao et al., 1999). In the current study, basal diets in all three phases were formulated to contain $0.5 \% \mathrm{P}$, and there were no variations in $\mathrm{P}$ concentration between treatments, thus making it difficult to explain the observed performance. There was good agreement between calculated and analysed levels of $\mathrm{Ca}$, but surprisingly the total $\mathrm{P}$ concentrations in the starter phase for all experimental diets were $0.3 \%$ higher than the formulated specification. This could have contributed to bone strength of birds from an early age; which might explain why there were no differences in tibia characteristics. Generally, broilers have been found to be sensitive to imbalances in mineral supply in their diets (McDevitt et al., 2006).

Despite this, the lack of effect on BBS from dietary MOLM supplementation is difficult to explain, because although calculated and analysed $\mathrm{P}$ and $\mathrm{Ca}$ levels were not different between treatments (Table 2), the extra $\mathrm{Ca}$ and $\mathrm{P}$ in Moringa leaves were expected to become systemically available to the birds. Bone ash content and BBS are the most commonly used parameters for assessing bioavailability for Ca and $\mathrm{P}$ (EMFEMA, 2002; Shaw et al., 2010). The ability of the bone architecture of an immature growing skeleton to withstand loads was reported to be genetically related, being further influenced by whether feed was restricted or offered ad libitum to the birds (Williams et al., 2004). Generally, the P requirement of the chick decreases with age. However, owing to poor utilization, a few studies have focused on $P$ requirements after three or four weeks of age to correspond with increases in feed intake by the broiler when faecal excretion is higher (Yan et al., 2001). Onyango et al. (2006) reported an increase in ileal digestibility of dry matter, energy, nitrogen and $\mathrm{P}$, but an accompanying decrease in the digestibility of Ca when the dietary level of $\mathrm{P}$ was increased. A similar observation was reported by McDevitt et al. (2006), who notes that dry bone weight and mineral content per unit length of modern broiler strains increase in direct proportion to the increase in BW. In contrast, inadequate dietary sources of Ca result in blood hypocalcaemia, leading to reduced bone strength and mineralization (Talaty et al., 2009a).

As with other tibia characteristics, there were no statistical differences in tibia ash percentage (Table 7). Although tibia ash weight was not significantly different between T4 and T1, it was highest in T4 and 
lowest in T2 $(P<0.05)$. This implies that the increase in dry bone weight and mineral content per unit bone length responds to mechanical forces placed on the bone (McDevitt et al., 2006; Whitehead, 2007; Talaty et al., 2009b). The weight of tibia ash has been found to be a more sensitive indicator of the amount of Ca and $\mathrm{P}$ in the diet (Hall et al., 2003). The normal content of starter diets is about $10 \mathrm{~g} \mathrm{Ca}$ and $4.5 \mathrm{~g}$ available $\mathrm{P} / \mathrm{kg}$ diet (NRC, 1994; Fleming, 2008). In view of the $\mathrm{Ca}$ and $\mathrm{P}$ levels in T1 and T4, including their Ca : P ratios, it is unlikely that low systemic mineral concentrations are the reason for the observed lower bone ash content in T4 and T5 (Williams et al., 2004).

Thus, the lack of difference in tibia ash percentage and BBS seen in this study suggests limited mineral availability and utilization efficiency at tissue level of birds fed the MOLM-supplemented diets. As a result it may be speculated that the bioavailability of $\mathrm{Ca}$ and $\mathrm{P}$ was limited in these birds or that birds had a problem in utilizing the minerals quickly enough because of their rapid growth rate (Williams et al., 2000). Furthermore, bioactive compounds in M. oleifera leaves have been reported to have a regulatory effect on birds' gastrointestinal tract, resulting in improved nutrient utilization efficiency (Mbikay, 2012), hence an increase in tibia ash percentage of these birds. Because birds in the negative control performed as well as birds in T1 and MOLM-supplemented diets, this agrees with the notion that well-nourished healthy chicks do not respond to antibiotic supplements when they are housed under clean and disinfected conditions (Hernandez et al., 2004). Although the percentage of tibia ash is commonly and routinely used as a measure of bone mineralization, the weight of the tibia ash proved to be a more sensitive indicator of bone mineralization (Hall et al., 2003). Moreover, bone ash can be a misleading measure of bone response because increases in total bone growth are possible without altering the percentage of bone ash (Cheng et al., 2004).

Table 7 Least square means ( \pm standard errors) of tibia ash and mineral composition of broilers (35 d) fed diets supplemented with or without Moringa oleifera leaf meal (MOLM)

\begin{tabular}{|c|c|c|c|c|c|c|}
\hline \multirow{2}{*}{$\begin{array}{l}\text { Variable } \\
(n=6)\end{array}$} & \multicolumn{5}{|c|}{ Dietary treatments } & \multirow{2}{*}{$P$-value } \\
\hline & $\mathrm{T} 1$ & $\mathrm{~T} 2$ & T3 & $\mathrm{T} 4$ & T5 & \\
\hline $\mathrm{Ca}(\%)$ & $31.4^{\mathrm{b}} \pm 2.17$ & $29.7^{b} \pm 0.95$ & $32.2^{\mathrm{b}} \pm 1.82$ & $39.0^{a} \pm 1.73$ & $30.6^{\mathrm{b}} \pm 0.56$ & $<0.001$ \\
\hline $\mathrm{P}(\%)$ & $15.7^{\mathrm{c}} \pm 0.17$ & $16.7^{\mathrm{bc}} \pm 0.19$ & $17.0^{b} \pm 0.30$ & $17.5^{\mathrm{ab}} \pm 0.23$ & $18.1^{a} \pm 0.27$ & $<0.001$ \\
\hline Ca: P (\%) & $2.0^{\mathrm{ab}} \pm 0.07$ & $1.8^{\mathrm{b}} \pm 0.06$ & $1.9^{\mathrm{ab}} \pm 0.13$ & $2.2^{a} \pm 0.10$ & $1.7^{\mathrm{b}} \pm 0.02$ & 0.002 \\
\hline Ash (\%) & $49.5 \pm 0.64$ & $48.7 \pm 0.17$ & $48.3 \pm 0.53$ & $48.2 \pm 0.30$ & $48.0 \pm 0.39$ & 0.149 \\
\hline Ash weight (g) & $52.0^{\mathrm{a}} \pm 1.49$ & $41.1^{b} \pm 2.89$ & $50.3^{\mathrm{ab}} \pm 2.12$ & $54.3^{a} \pm 0.44$ & $49.7^{\mathrm{ab}} \pm 3.43$ & 0.006 \\
\hline
\end{tabular}

\footnotetext{
${ }^{a, b, c}$ Means within a row with no common superscript differ significantly $(P<0.05)$.

$\mathrm{T}_{1}$, positive control, $668 \mathrm{mg}$ salinomycin, $500 \mathrm{mg}$ zinc bacitracin; $\mathrm{T}_{2}, \mathrm{~T}_{3}$ and $\mathrm{T}_{4}$ contained graded levels of $M$. oleifera leaf meal (MOLM); $T_{5}$ : a negative control diet with no supplementation.

$\mathrm{Ca}=$ calcium; $\mathrm{P}=$ phosphorus.
}

The highest tibia Ca content $(P<0.05)$ was noted in T4, with T2 having the lowest $(39.0 \pm 1.73$ vs. $29.7 \pm 0.95$; Table 7) amount. Similarly, T4 had the highest $(P<0.05) \mathrm{P}$ concentration, and lowest in T1 $(17.5$ \pm 0.23 vs. $15.7 \pm 0.17)$. The highest $(P<0.05) \mathrm{Ca}$ : $P$ ratio was obtained in T4 $(2.24 \pm 0.104)$ and was at its lowest in T5 (1.69 \pm 0.017$)$. According to Williams et al. (2000), the variations in bone ash Ca and P among treatments bear no resemblance to the composition of these minerals in the diets. Major ingredients in poultry diets are of plant origin, with $60 \%-80 \%$ of $\mathrm{P}$ being in the form of phytic acid, rendering it biologically unavailable, implying that it cannot be utilized. Instead, it is excreted to the environment (Kornegay, 1999; Foidl et al., 2001). Generally, Ca has a relatively high availability from most feedstuffs, but the availability of phosphorus varies largely depending on the source (Waldenstedt, 2006). As a result, in P deficiency, it is unlikely that birds would respond to phytase supplementation if Ca was also limiting (Yan et al., 2006).

Critically, although phytase was not added in the current study, a high molar $\mathrm{Ca}$ : phytate ratio in the diet has been reported to result in the formation of extremely insoluble Ca-phytate complexes under intestinal conditions, making the phytate molecule inaccessible to the phytase enzyme (Kornegay, 1999), particularly in weak acid or neutral pH conditions of the gastrointestinal tract of chickens (Pallauf \& Rimbach, 1997). Nonetheless, absorption and homeostasis of dietary $\mathrm{Ca}$ and $\mathrm{P}$ are believed to be maximized at a dietary ratio of $2 \mathrm{Ca}$ : $1 \mathrm{P}$ ratio (NRC, 1994; Whitehead, 2007). The mature bone mineral, however, is generally accepted to have a structure close to that of the calcium phosphate, hydroxyapatite, which has a 
molar Ca : P ratio of 1.67: 1 (Williams et al., 2000). Surprisingly, the current study shows a Ca : P ratio of $1.69: 1$, which resulted in the lowest tibia ash and breaking strength. On the contrary, while the transient high $\mathrm{Ca}$ : $\mathrm{P}$ ratio is influenced by dietary available $\mathrm{P}$, it seems unlikely to have any effect on bone strength (Williams et al., 2000).

Tibia Ca was positively correlated with tibia ash percentage, and TW before and after drying, but not with BW, BBS, P content or tibia length (Table 9). The BBS was positively correlated to tibia ash percentage, TW, tibia length and bone phosphorus content, but no significant differences $(P<0.05)$ were observed between these variables. In modern meat-type chickens, bone strength and development are closely linked to the expression of genetic potential for maximum lean muscle deposition (Williams et al., 2004). Overall, the results of the current study suggest that bone mineral content and bone mineral density may be more sensitive indicators of dietary $\mathrm{Ca}$ and $\mathrm{P}$ concentrations in broilers than tibia breaking strength (Venäläinen et al., 2006).

Furthermore, other factors such as management, nutrition, hygiene, and concurrent diseases may influence leg integrity, both under field and experimental conditions, even when diet contents appear to be adequate (Waldenstedt, 2006). Although Lewis et al. (2009) found little probability that photoperiod may contribute to tibial integrity in practical terms, photoperiod does influence bone development during early growth through vitamin D metabolism. Broiler skin plays an important role in vitamin D metabolism, because it contains vitamin D precursors, which can be converted to vitamin $D_{3}$ when birds are exposed to ultraviolet light (Onyango et al., 2006). It is common knowledge that in the presence of vitamin D, the systemic availability and utilization of $\mathrm{Ca}$ and $\mathrm{P}$ are increased. Therefore, under continuous lighting, as in the present study, the observed ash weight, Ca/P ratio, as well as $\mathrm{Ca}$ and $\mathrm{P}$ in tibia ash could be expected. Nutritionally, another study showed an increase in bone density when broilers were fed diets containing Solanum glaucophyllum, a plant containing a glycoside of 1,25-dihydroxyvitamin D when compared with the nonphytate $\mathrm{P}$ basal diet group (Cheng et al., 2004).

Table 8 Pearson correlation coefficients ( $r$ ) among tibia characteristics of broilers (35 d) fed diets supplemented with or without Moringa oleifera leaf meal (MOLM)

\begin{tabular}{|c|c|c|c|c|c|c|c|c|c|}
\hline Variable & BW & TW & DW & LW & TL & BBS & $\mathrm{Ca}$ & $\mathbf{P}$ & TW/TL \\
\hline Ash & -0.256 & $-0.524^{\star \star}$ & $-0.434^{\star}$ & -0.327 & 0.103 & 0.042 & 0.124 & $-0.499^{\star}$ & $-0.532^{* *}$ \\
\hline BW & & $-0.070^{\mathrm{NS}}$ & $0.246^{\mathrm{NS}}$ & 0.315 & 0.121 & -0.079 & -0.050 & $0.205^{\mathrm{NS}}$ & $-0.090^{\mathrm{NS}}$ \\
\hline TW & & & $0.667^{\star \star}$ & $0.563^{\star \star \star}$ & -0.055 & 0.216 & 0.213 & $-0.098^{\mathrm{NS}}$ & $0.977^{\star \star \star *}$ \\
\hline DW & & & & $0.700^{\star \star *}$ & 0.038 & -0.172 & 0.357 & $-0.016^{\mathrm{NS}}$ & $0.632^{\star \star \star}$ \\
\hline LW & & & & & -0.034 & -0.059 & 0.195 & $0.539^{* *}$ & $0.551^{\star *}$ \\
\hline TL & & & & & & 0.227 & -0.250 & $-0.151^{\mathrm{NS}}$ & $-0.265^{\mathrm{NS}}$ \\
\hline BBS & & & & & & & -0.059 & $0.029^{\mathrm{NS}}$ & $0.164^{\mathrm{NS}}$ \\
\hline $\mathrm{Ca}$ & & & & & & & & $0.078^{\mathrm{NS}}$ & $0.241^{\mathrm{NS}}$ \\
\hline$P$ & & & & & & & & & $-0.044^{\mathrm{NS}}$ \\
\hline
\end{tabular}

NS = non-significant; ${ }^{\star} P \leq 0.05 ;{ }^{\star \star} P \leq 0.01 ;{ }^{\star \star \star} P \leq 0.001 ; \mathrm{Ca}=$ calcium; $\mathrm{P}=$ phosphorus; $\mathrm{BW}=$ bodyweight; $\mathrm{BBS}=$ bone breaking strength; TW = tibia weight; DW = Dried defatted tibia weight; LW = loss in tibia weight; TL = tibia length.

Phosphorus, on the other hand, was positively correlated with LW, TW, DW and TL, while it was negatively correlated with and significantly different from tibia ash percentage $(r=-0.499 ; P<0.01)$. However, although no correlation or linear relationships were observed between BW at 35 days of age and TW, DW or TL (Tables 8 and 9), a positive correlation $(r=0.667)$ and a highly significant difference $(P<0.01)$ were observed between TW and DW. Perhaps, the positive correlation observed between BW, dry bone weight and bone length depicts the genetic relationship that exists among these parameters. Tibiae from birds in the positive control, T1, had the lowest $(P<0.05)$ loss in TW following drying and fat removal from these bones, compared with birds that were supplemented with MOLM. Tibia weight loss owing to removal of moisture, polar and non-polar lipids was positively correlated and significantly different to TW $(r=0.563 ; P<0.01)$ and DW $(r=0.700 ; P<0.01)$. The positive effects of using plant extracts as additives has been attributed to increased solubility of minerals owing to increased bacterial production of short-chain fatty 
acids, enlargement of the absorption surface by promoting proliferation of enterocytes and increased expression of calcium binding proteins (Scholz-Ahrens et al., 2007).

Table 9 Linear relationship between tibia ash, bodyweight and tibia characteristics of broilers (35 d) fed diets supplemented with or without Moringa oleifera leaf meal (MOLM)

\begin{tabular}{|c|c|c|c|c|c|c|c|}
\hline \multirow{2}{*}{ Variable } & \multirow[t]{2}{*}{ Equation } & \multirow[t]{2}{*}{$\mathbf{R}^{2}$} & \multicolumn{2}{|c|}{ Coefficient } & \multicolumn{2}{|c|}{ SE } & \multirow[t]{2}{*}{ Sig. level } \\
\hline & & & Intercept & $x$-variable & Intercept & $\mathrm{x}$-variable & \\
\hline BW & $y=0.0024 x+2.049$ & 0.87 & 3.012 & -0.017 & 0.600 & 0.012 & NS \\
\hline BBS & $y=2.588 x+236.16$ & 0.94 & 225.664 & 2.884 & 631.961 & 13.024 & NS \\
\hline $\mathrm{Ca}$ & $y=0.141 x+25.50$ & 0.86 & 8.805 & 0.490 & 35.849 & 0.739 & NS \\
\hline$P$ & $y=0.033 x+15.33$ & 0.98 & 37.924 & -0.431 & 6.875 & 0.142 & ** \\
\hline TW & $y=0.054 x+8.479$ & 0.97 & 47.014 & -0.739 & 11.011 & 0.227 & ** \\
\hline DW & $y=0.042 x+8.488$ & 0.94 & 34.150 & -4.486 & 9.243 & 0.190 & * \\
\hline TL & $y=0.010 x+9.134$ & 0.90 & 8.460 & 0.028 & 2.453 & 0.051 & NS \\
\hline
\end{tabular}

NS: non-significant; ${ }^{\star} P<0.05 ;{ }^{\star} \mathrm{P}<<0.01$; $\mathrm{Ca}=$ calcium; $\mathrm{P}=$ phosphorus; $\mathrm{BW}=$ bodyweight; $\mathrm{BBS}=$ bone breaking strength; TW = tibia weight; $\mathrm{DW}=$ dried defatted tibia weight; $\mathrm{TL}=$ tibia length.

\section{Conclusion}

Commercial meat-type chickens have been developed for improved growth and meat production. However, the skeleton remains a potential weak link relative to providing physical support to heavier BW at a very young age. Bone morphology and mineral density are important factors in measuring bone quality in relation to their support for muscle growth and development. The increased tibia $\mathrm{Ca}$ and $\mathrm{P}$ contents, $\mathrm{Ca} / \mathrm{P}$ ratio and ash weight of birds that were supplemented with MOLM indicate that Moringa oleifera leaves has potential to be used as an alternative additive to AGPs. The improved BW, ADG and FCR could be a reflection of the attributes induced by bioactive compounds in MOLM to influence intestinal nutrient utilization, thereby improving tibia integrity and inorganic composition of tibia bones. Nonetheless, in future studies utilization efficiency of $\mathrm{P}$ and Ca should be measured when MOLM is supplemented in broiler diets. The use of phytase may also be recommended. This would give a clear understanding of the amount of these minerals that are utilized by the bird, and at what rate. It would also be necessary to quantify the excreted levels.

\section{Acknowledgements}

The authors are grateful to Govan Mbeki Research and Development Centre of the University of Fort Hare and National Research Foundation (NRF) of South Africa Thuthuka Research Grant for funding this work.

\section{References}

Almeida Paz, I.C.L. \& Bruno, L.D.G., 2006. Bone mineral density: A review. Braz. J. Poult. Sci. 8, 69-73.

AOAC, 2000. Official Methods of Analysis, 17th ed. Association of Official Analytical Chemists, Arlington, VA, USA.

Applegate, T.J. \& Lilburn, M.S., 2002. Growth of the femur and tibia of a commercial broiler line. Poult. Sci. 81, 1289-1294.

Cheng, Y.H., Goff, J.P., Sell, J.L., Dallorso, M.E., Gil, S., Pawlak, S.E. \& Horst, R.L., 2004. Utilizing Solanum glaucophyllum alone or with phytase to improve phosphorus utilization in broilers. Poult. Sci. 83, 406413.

Coon, C.N. \& Manangi, M.K., 2008. Phosphorus retention: Ca: P ratio, calcium particle size, and phytase for poultry. Proceedings of the "Midwest Poultry Federation Convention", St. Paul, Minnesota, U.S.A.

EMFEMA, 2002. Bioavailability of major and trace minerals. International Association of the European (EU) Manufacturers of Major, Trace and Specific Feed Mineral Materials.

Fleming, R.M., 2008. Nutritional factors affecting poultry bone health. Proc. Nutr. Soc. 67, 177-183. 
Foidl, N., Makkar, H.P.S. \& Becker, K., 2001. The potential of Moringa oleifera for agricultural and industrial uses. What development potential for Moringa products? October $20^{\text {th }}$-November 2 nd 2001 . Dar es Salam, Tanzania.

Hall, L.E., Shirley, R.B., Bakalli, R.I., Aggrey, S.E., Pesti, G.M. \& Edwards Jr., H.M., 2003. Power of two methods for the estimation of bone ash of broilers. Poult. Sci. 82, 414-418.

Harter-Dennis, J., 1999. Phytase applications in commercial broiler diets in Maryland. Biotechnology in the feed industry: Proceeding of Alltech's $15^{\text {th }}$ Annual Symposium, Edited by Lyons, T.P. \& Jacques, K.A. pp. 511-519.

Hernandez, F., Madrid, J., Garcia, V., Orengo, J. \& Megias, M.D., 2004. Influence of two plant extracts on broiler performance, digestibility and digestive organ size. Poult. Sci. 83, 169-174.

IBM Corp. Released, 2011. IBM SPSS Statistics for Windows, Version 20.0. Armonk, NY: IBM Corp.

Joshi, P. \& Mehta, D., 2010. Effect of dehydration on the nutritive value of drumstick leaves. J. Metabol. Syst. Biol. 1 (1), 5-9.

Kasetti, R.B., Nabi, S.A., Swapna, S. \& Apparao, C., 2012. Cinnamic acid as one of the antidiabetic active principle(s) from the seeds of Syzygium alternifolium. Food Chem. Toxicol. 50, 1425-1431.

Kornegay, E.T., 1999. Feeding to reduce nutrient excretion: effects of phytase on phosphorus and other nutrients. Biotechnology in the feed industry: Proceeding of Alltech's $15^{\text {th }}$ Annual Symposium, Edited by Lyons, T.P. \& Jacques, K.A. pp. 461-489.

Leach Jr, R.M. \& Lilburn, M.S., 1992. Current knowledge on the etiology of tibial dyschondroplasia in the avian species. Poult. Sci. Rev. 4,57-65.

Lewis, P.D., Danisman, R. \& Gous, R.M., 2009. Photoperiodic responses of broilers: I. Growth, feeding behaviour, and testicular growth. Br. Poult. Sci. 50, 657-666.

Makkar, H.P.S. \& Becker, K., 1997. Nutrients and anti-quality factors in different morphological parts of the Moringa oleifera tree. J. Agric. Sci. 128, 311-322.

Mbikay, M., 2012. Therapeutic potential of Moringa oleifera leaves in chronic hyperglycemia and dyslipidemia: A Review. Front. Pharmacol. 3, 1-12.

McDevitt, R.M., McEntee, G.M. \& Rance, K.A., 2006. Bone breaking strength and apparent metabolisability of calcium and phosphorus in selected and unselected broiler chicken genotypes. Br. Poult. Sci. 47, 613-621.

Moyo, B., Oyedemi, S., Masika, P.J. \& Muchenje, V., 2012. Polyphenolic content and antioxidant properties of Moringa oleifera leaf extracts and enzymatic activity of liver from goats supplemented with Moringa oleifera leaves/ sunflower seed cake. Meat Sci. 91, 441-447.

Nkukwana, T.T., Muchenje, V., Peterse, E., Masika, P.J., Mabusela, T.P., Hoffman, L.C. \& Dzama, K., 2014. Effect of Moringa oleifera leaf meal on growth performance, apparent digestibility, digestive organ size and carcass yield in broiler chickens. Livest. Sci. 161, 139-146.

NRC, 1985. National Research Council (Guide for the Care and Use of Laboratory Animals), Publication No. 85-123. National Academy Press, Washington DC, USA.

NRC, 1994. Nutrient Requirements of Poultry, 9th ed., National Academy Press, Washington DC, USA.

Onyango, E.M., Asem, E.K. \& Adeola, O., 2006. Dietary cholecalciferol and phosphorus influence intestinal mucosa phytase activity in broiler chicks. Br. Poult. Sci. 47, 632-639.

Pallauf, J. \& Rimbach, G., 1997. Nutritional significance of phytic acid and phytase. Arch. Anim. Nut. 52, 301-319.

Rao, S.V.R., Reddy, V.R. \& Reddy, V.R., 1999. Enhancement of phytate phosphorus availability in the diets of commercial broilers and layers. Anim. Feed Sci. Technol. 79, 211-222.

Scholz-Ahrens, K.E., Ade, P., Marten, B., Weber, B., Timm, W., Asîl, Y., Gluër, C.C. \& Schrezenmeir, J., 2007. Prebiotics, probiotics, and symbiotics affect mineral absorption, bone mineral content, and bone structure. J. Nutr. 137, 838S-846S.

Shaw, A.L., Blake, J.P. \& Moran, E.T., 2010. Effects of flesh attachment on bone breaking and of phosphorus concentration on performance of broilers hatched from young and old flocks. Poult. Sci. 89, 295-302.

Talaty, P.N., Katanbaf, M.N. \& Hester, P.Y., 2009a. Life cycle changes in bone mineralization and bone size traits of commercial broilers. Poult. Sci. 88, 1070-1077.

Talaty, P.N., Katanbaf, M.N. \& Hester, P.Y., 2009b. Variability in bone mineralization among purebred lines of meat-type chickens. Poult. Sci. 88, 1963-1974.

Van Soest, P.J., Robertson, J.B. \& Lewis, B.A., 1991. Methods for dietary fiber, neutral detergent fiber and non-starch polysaccharides in relation to animal nutrition. J. Dairy Sci. 74, 3583-3597.

Venäläinen, E., Valaja, J. \& Jalava, T., 2006. Effects of dietary metabolisable energy, calcium and phosphorus on bone mineralisation, leg weakness and performance of broiler chickens. Br. Poult. Sci. 47, 301-310. 
Waldenstedt, L., 2006. Nutritional factors of importance for optimal leg health in broilers: A review. Anim. Feed Sci. Technol. 126, 291-307.

Wallace, R.J., Oleszek, W., Franz, C., Hahn, I., Baser, K.H.C., Mathe, A. \& Teichmann, K., 2010. Dietary plant bioactives for poultry health and productivity. Br. Poult. Sci. 51, 461-487.

Whitehead, C.C., 2007. Causes and prevention of bone fracture. Proc. 19th Aust. Poult. Sci. Symp., 122-129.

Williams, B., Solomon, S., Waddington, D., Thorp, B. \& Farquharson, C., 2000. Skeletal development in the meat-type chicken. Br. Poult. Sci. 41, 141-149.

Williams, B., Waddington, D., Murray, D.H. \& Farquharson, C., 2004. Bone strength during growth: Influence of growth rate on cortical porosity and mineralization. Calc. Tiss. Int. 74, 236-245.

Windisch, W., Schedle, K., Plitzner, C. \& Kroismayr, A., 2008. Use of phytogenic products as feed additives for swine and poultry. J. Anim. Sci. 86, E140-E148.

Yan, F., Kersey, J.H. \& Waldroup, P.W., 2001.Phosphorus requirements of broiler chicks three to six weeks of age as influenced by phytase supplementation. Poult. Sci. 80, 455-459.

Yan, F., Kersey, J.H., Fritts, C.A. \& Waldroup, P.W.,2006. Effect of phytase supplementation on the calcium requirement of broiler chicks. Int. Poult. Sci. 5 (2), 112-120. 